\title{
PENERAPAN METODE EXPONENTIAL SMOOTHING PADA SISTEM PENJUALAN TERLARIS DI PT GRAHA PRIMA MENTARI
}

\author{
Application of the Exponential Smoothing Method on the Best Sales System At PT \\ Graha Prima Mentari
Siti Nurhaliza ${ }^{1}$, Muhammad Hatta ${ }^{2}$, Amroni $^{3}$
${ }^{1,2,3}$ Program Studi Sistem Informasi, Fakultas Teknologi Informasi, Universitas Catur Insan Cendekia, Indonesia

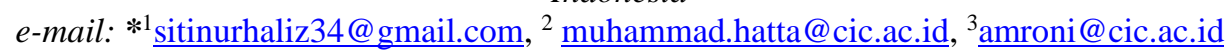

\begin{abstract}
Abstrak
PT Graha Prima Mentari melakukan kegiatan jual beli produk minuman kemasan kepada toko dan outlet yang ada di sekitar Kota Cirebon dengan menggunakan perhitungan secara manual dan belum memiliki sistem perhitungan penjualan terlaris berdasarkan total penjualan harian yang diperoleh. Penjualan terhadap toko dan outlet sebagai tolak ukur untuk menentukan banyaknya produk terlaris yang ditentukan, peminat produk yang banyak dapat mempengaruhi hasil perhitungan produk terlaris sesuai pencapaian penjualan masing - masing produk yang tersedia, untuk mencapai hasil produk terlaris yang memilki tiga kriteria yaitu produk terlaris ditentukan oleh frekuensi penjualan produk secara berulang, Variable produk terlaris ditentukan oleh banyaknya qty atau jumlah produk yang terjual, produk terlaris ditentukan dari banyaknya customer yang membeli salah satu produk yang tersedia. Hasil pencapaian penjualan terlaris yang dibedakan pada tiga kriteria merupakan informasi mengenai pencapaian kinerja agent yang dapat dihitung pencapaiannya, sehingga dapat menunjukkan tingkat keberhasilan perhitungan dan kenyataan yang dicapai. Dengan adanya masalah dan dampak pada PT. Graha Prima Mentari, maka solusi dan kesimpulan dari permasalahan adalah diperlukan adanya web sistem penerapan metode Exponential Smoothing pada system informasi penjualan terlaris di PT. Graha Prima Mentari yang dapat membantu perusahaan menentukan perhitungan secara tersistem, baik dan benar adanya laporan yang dibutuhkan oleh perusahaan tersebut.
\end{abstract}

Kata kunci-exponential smoothing, pre order, reorder point, penjualan terlaris, sistem informasi

\begin{abstract}
PT Graha Prima Mentari conducts buying and selling of packaged beverage products to shops and outlets around the city of Cirebon using manual calculations and does not yet have a best-selling sales calculation system based on the total daily sales obtained. Sales of shops and outlets as a benchmark for determining the number of best-selling products are determined, many product enthusiasts can affect the results of the calculation of the best-selling products according to the sales achievement of each available product, to achieve the best-selling product results that have three criteria, namely the best-selling product is determined by the frequency of product sales repeatedly, the best-selling product variable is determined by the number of qty or the number of products sold, the best-selling product is determined by the number of customers who buy one of the available products. The results of the achievement of bestselling sales which are distinguished on three criteria are information about the achievement of agent performance that can be calculated, so that it can show the level of success of the calculation and the reality achieved. With the problems and impacts on PT. Graha Prima Mentari, then the solution and conclusion of the problem is that there is a need for a web system for applying the Exponential Smoothing method to the best-selling sales information system at PT. Graha Prima Mentari who can help companies determine the calculation in a systematic, good and correct way for the reports needed by the company. Keywords - exponential smoothing, pre order, reorder point, best selling, information system
\end{abstract}

Informasi Artikel:

Submitted: Oktober 2021, Accepted: November 2021, Published: November 2021

ISSN: 2685-4902 (media online), Website: http://jurnal.umus.ac.id/index.php/intech 


\section{PENDAHULUAN}

PT. Graha Prima Mentari adalah perusahan di bidang penjualan minuman bersoda yang terdapat beberapa masalah mengenai mengurutkan hasil penjualan terlaris dalam produk tertentu dan dalam periode tertentu.

Penjualan yang baik adalah penjualan yang memperhatikan segi pesatnya kenaikan rating penjualan dari waktu dalam suatu periode tertentu[2]. Dalam hal ini perusahaan harus memiliki strategi analisis yang baik untuk dapat menentukan dan menyiapkan barang yang penjualannya baik agar selalu ready stok dan tidak kehabisan maupun kekurangan, serta memiliki batas minimum sisa jumlah barang yang nantinya data tersebut menjadi data purchase order berikutnya dan perhitungan batas minimum barang ini akan diperhitungkan memakai metode reorder point [2][3].

Reorder point merupakan dimana barang yang ada di gudang yang habis harus ditambahkan persediaannya sebelum stok barang habis, salah satu manajemen persediaan yang memiliki tujuan utama untuk meminimalisir atau menekan terjadinya situasi kehabisan stok[3]. Dengan melakukan perhitungan reorder point yang tepat, maka kita tidak perlu lagi khawatir akan terjadinya penumpukan barang di gudang karena sudah memesan banyak yang terlalu banyak, atau harus menghadapi kekecewaan konsumen karena kehabisan stok.

Ketersedian data dan informasi yang banyak dan kebutuhan akan informasi dan atau pengetahuan sebagai pendukung pengambilan keputusan untuk membentuk solusi bisnis dibidang sistem informasi merupakan cikal dari lahirnya teknologi Exponential Smoothing. Penggunaan teknik Exponential Smoothing diharapkan dapat membantu mempercepat proses pengambilan keputusan, memungkinkan perusahan untuk mengelola informasi yang terkandung didalam data transaksi menjadi pengetahuan yang baru dan tak secara langsung mengetahui data warehouse menjadi Exponential Smoothing [5].

Dengan masalah tersebut diatas dibutuhkan suatu aplikasi berbasis web yang dapat memprediksi dan analisis penjualan terlaris[4]. Sistem informasi berbasis web ini dibangun untuk memprediksi penjualan minuman terlaris per periode, dengan memiliki tiga penentuan variable dalam penjualan terlaris yang dimaksudkan oleh penulis yaitu variable produk terlaris ditentukan oleh frekuensi penjualan produk secara berulang, variable produk terlaris ditentukan oleh banyaknya qty atau jumlah produk yang terjual, dan variable produk terlaris ditentukan dari banyaknya customer yang membeli salah satu produk[16][17].

\section{METODE PENELITIAN}

Dalam penerapan analisis ini menggunakan Penelitian Kuantitatif yaitu metode yang lebih menekankan pada aspek pengukuran secara obyektif terhadap fenomena sosial. Untuk dapat melakukan pengukuran, setiap fenomena sosial di jabarkan kedalam beberapa komponen masalah, variabel dan indikator. Setiap variable yang di tentukan di ukur dengan memberikan simbol- simbol angka yang berbeda-beda sesuai dengan kategori informasi yang berkaitan dengan variabel tersebut. Dengan menggunakan simbol-simbol angka tersebut, teknik perhitungan secara kuantitatif matematik dapat di lakukan sehingga dapat menghasilkan suatu kesimpulan yang belaku umum di dalam suatu parameter.

Untuk perhitungannya menggunakan metode Exponential Smoothing merupakan prosedur perbaikan terus-menerus pada peramalan terhadap objek pengamatan terbaru[15]. Metode peramalan ini menitik-beratkan pada penurunan prioritas secara eksponensial pada objek pengamatan yang lebih tua. Dalam pemulusan eksponensial atau exponential smoothing terdapat satu atau lebih parameter pemulusan yang ditentukan secara eksplisit, dan hasil ini menentukan bobot yang dikenakan pada nilai observasi. Dengan kata lain, observasi terbaru akan diberikan prioritas lebih tinggi bagi peramalan daripada observasi yang lebih lama. 


\section{Tahapan Penelitian}

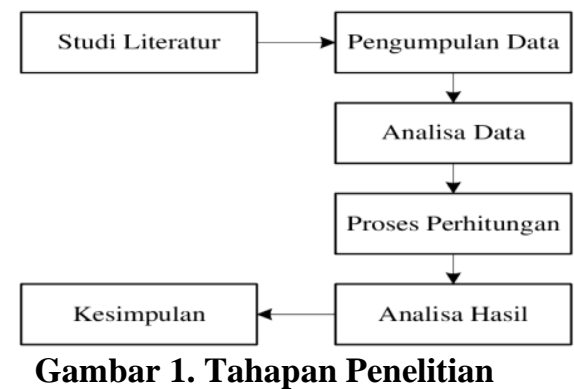

1. Studi Pendahuluan (Literature)

Pada Gambar 1 adalah rangkaian dalam tahapan penelitian, dilakukan studi literatur dan studi lapangan. Studi literatur dilakukan untuk mengkaji dan mengetahui secara teoritis metode yang dipakai dalam metode pemecahan masalah yaitu menggunakan metode Exponential Smoothing. Sedangkan studi lapangan adalah mempelajari bagaiman metode yang sedang berjalan terkait objek penelitian di Perusahaan Minuman Pt. Graha Prima Mentari.

2. Pengumpulan Data dan Pengolahan Data

Pada tahap yang ketiga dilakukan pengumpulan data - data yang diperlukan sebagai bahan untuk memcahkan masalah yang telah dirumuskan pada tahap kedua. Setelah data terkumpul, dilakukan pengolahan data yang akan digunakan pada tahap analisis. Pada proses analisis dikaji data - data yang ada menggunakan metode yang telah peneliti pelajari pada tahap awal.

3. Analisis dan Perhitungan

Pada tahap ini dilakukan analisa dan peringkat hasil pembahasan masalah dengan metode Exponential Smoothing fokus pada nilai rating penjualan terlaris. Pada umum pembahasan masalah - masalah berisi tahapan - tahapan dan perhitungan data - data yang ada menggunakan rumus valid metode Exponential Smoothing. Setiap tahapan akan dibahas secara maksimal sesuai langkah - langkah yang terdapat pada metode Exponential Smoothing. Dari hasil pengolahan data pada tahap sebelumnya akan digunakan sebagai bahan analisis lebih lanjut guna mendapatkan pemecahan masalah. Hasil pemecahan masalah ini diharapkan akan dapat memberikan alternative perhitungan lebih baik dalam menentukan rating penjualan terlaris pada perusahaan distributor PT. Graha Prima Mentari guna untuk menetapkan barang purchase order diperiode berikutnya.

4. Analisa Hasil

Pada tahap ini, peneliti melakukan penyimpulan terhadap hasil penelitian yang telah dilakukan berdasarkan hasil pengolahan data menggunakan metode Exponential Smoothing. Kesimpulan ini berupa pernyataan yang diambil dari perhitungan yang dihasilkan dengan metode penelitian serta hasil dari proses penelitian diatas dapat menyimpulkan bahwa penerepan metode exponential smoothing pada sistem informasi penjualan terlaris di PT. Graha Prima Mentari dapat berjalan baik dengan menghasilkan data penjualan yang akurat dan sesuai sehingga dapat digunakan untuk purchase order kepada supplier[11][12].

\section{Gambaran dan Implementasi}

Pemodelan yang digunakan dalam perancangan sistem adalah unified modelling language (UML). Use case diagram menyajikan interaksi antara use case dan actor. Dimana aktor dapat berupa orang, peralatan atau sistem lain yang berinteraksi dengan sistem yang sedang dibangun. Use case menggambarkan fungsionalitas sistem atau persyaratan yang harus dipenuhi sistem dari pandangan pemakai. Dalam analisis ini terdapat dua aktor yang berkaitan yaitu user admin dan user kepala cabang. 


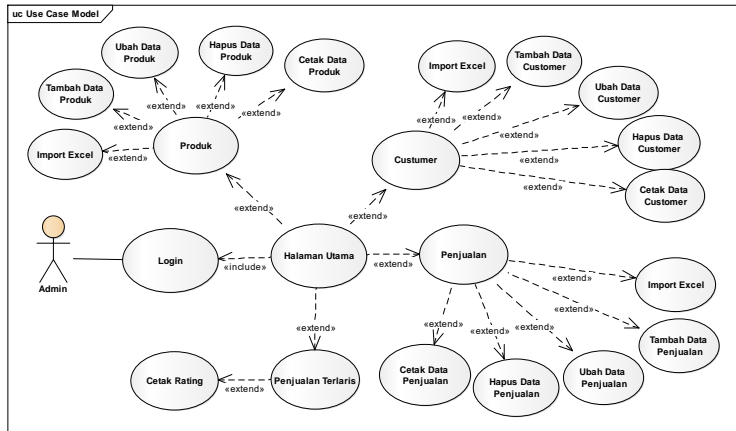

Gambar 2. Use Case User Admin

Gambar 2 menjelaskan proses bahwa rancangan use case diagram sistem diatas merupakan proses alur sistem informasi yang diajukan penulis secara tersistem dan terkomputerisasi, user diatas yaitu admin yang dimana bertugas untuk lebih banyak dalam mengolah master data sistem yang terbagi yang nantinya akan diolah input serta import data setiap harinya sesuai penjualan yang terlaksana.

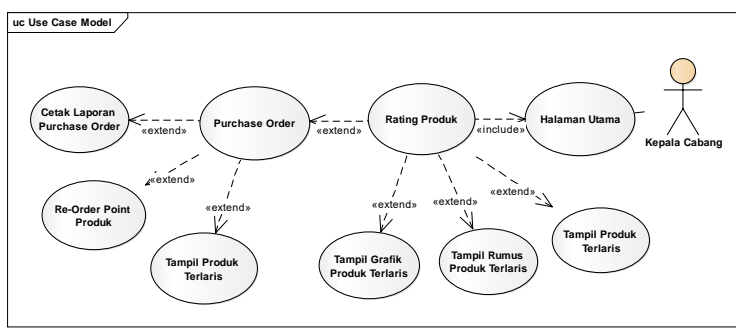

Gambar 3. Use Case User Kepala Cabang

Gambar 3 menjelaskan proses bahwa rancangan use case diagram sistem diatas merupakan proses alur sistem informasi yang diajukan penulis secara tersistem dan terkomputerisasi, user diatas yaitu kepala cabang yang dimana bertugas untuk memfilter data penjualan harian menjadi data rating produk secara urut dengan batas minimum stok produk yang ada yang nantinya akan dibuat sebagai laporan data purchase order.

\section{Dasar Teori}

Rumus dan Perhitungan Data

Penulis melakukan studi kasus lapangan pada perusahaan terkait mengenai data yang akan diolah dan analisis. Dalam studi kasus ini penulis mewawancarai kepala cabang serta admin untuk mengetahui alur penjualan yang nantinya akan dipakai pada data-data penjualan dari masing-masing periode yang dipakai yaitu periode bulanan. Penulis mengolah dan menganalisis total akhir penjualan gabungan dari bulan januari 2021 sampai bulan mei 2021. Untuk total penjualan terhitung dalan jumlah carton.

Untuk perhitungannya menggunakan metode Exponential Smoothing merupakan prosedur perbaikan terus-menerus pada peramalan terhadap objek pengamatan terbaru[8][9]. Metode peramalan ini menitik-beratkan pada penurunan prioritas secara eksponensial pada objek pengamatan yang lebih tua. Dalam pemulusan eksponensial atau exponential smoothing terdapat satu atau lebih parameter pemulusan yang ditentukan secara eksplisit, dan hasil ini menentukan bobot yang dikenakan pada nilai observasi. Dengan kata lain, observasi terbaru akan diberikan prioritas lebih tinggi bagi peramalan daripada observasi yang lebih lama[13].

$F t=($ a Ft -1$)+(1-$ a At -1$)$ 
Ft-1 = Perkiraan untuk periode sebelumnya.

At-1 = Permintaan nilai aktual untuk periode tersebut.

$\mathrm{a}=$ Berat (harus antara 0 dan 1). Semakin dekat ke nol, semakin kecil bobotnya.

Tabel 1. Total Data Penjualan Bulanan

\begin{tabular}{cll}
\hline Periode & \multicolumn{1}{c}{ Bulan } & $\begin{array}{c}\text { Permintaan } \\
\text { Aktual }\end{array}$ \\
\hline \multicolumn{3}{c}{ TAHUN 2021 } \\
\hline $\mathbf{1}$ & Januari & 75,825 \\
\hline $\mathbf{2}$ & Februari & 51,530 \\
\hline $\mathbf{3}$ & Maret & 93,711 \\
\hline $\mathbf{4}$ & April & 134,718 \\
\hline $\mathbf{5}$ & Mei & 155,478 \\
\hline
\end{tabular}

Tabel 2. Perhitungan Rumus Konstanta 0.1, 0.2

Bulan Permintaan Ramalan (Ft+1)

Aktual

\begin{tabular}{|c|c|c|c|}
\hline \multicolumn{2}{|c|}{ TAHUN 2021} & $\alpha=0.1$ & $\alpha=0.2$ \\
\hline Januari & 75,825 & 0 & 0 \\
\hline Februari & 51,530 & 75,825 & 75,825 \\
\hline Maret & 93,711 & 53,960 & 56,389 \\
\hline April & 134,718 & 89,736 & 86,247 \\
\hline Mei & 155,478 & 130,220 & 125,024 \\
\hline
\end{tabular}

Tabel 3. Perhitungan Rumus Konstanta 0.3, 0.4

\begin{tabular}{lccc}
\hline \multicolumn{1}{c}{ Bulan } & $\begin{array}{c}\text { Permintaan } \\
\text { Aktual }\end{array}$ & \multicolumn{2}{c}{ Ramalan $(\mathbf{F t + 1 )}$} \\
\multicolumn{2}{c}{ TAHUN 2021 } & $\boldsymbol{\alpha}=\mathbf{0 . 3}$ & $\boldsymbol{\alpha}=\mathbf{0 . 4}$ \\
\hline Januari & 75,825 & 0 & 0 \\
\hline Februari & 51,530 & 75,825 & 75,825 \\
\hline Maret & 93,711 & 58,819 & 61,248 \\
\hline April & 134,718 & 83,243 & 80,726 \\
\hline Mei & 155,478 & 119,276 & 113,121 \\
\hline
\end{tabular}

Tabel 4. Perhitungan Rumus Konstanta 0.5, 0.6

Bulan Permintaan Ramalan $(\mathrm{Ft}+1)$

Aktual

\begin{tabular}{llll}
\hline \multicolumn{2}{c}{ TAHUN 2021 } & $\boldsymbol{\alpha}=\mathbf{0 . 5}$ & $\boldsymbol{\alpha}=\mathbf{0 . 6}$ \\
\hline Januari & 75,825 & 0 & 0 \\
\hline Februari & 51,530 & 75,825 & 75,825 \\
\hline Maret & 93,711 & 63,678 & 66,107 \\
\hline April & 134,718 & 78,694 & 77,149 \\
\hline Mei & 155,478 & 106,706 & 100,176 \\
\hline
\end{tabular}


Tabel 5. Perhitungan Rumus Konstanta 0.7, 0.8

\begin{tabular}{|c|c|c|c|}
\hline Bulan & $\begin{array}{c}\text { Permintaan } \\
\text { Aktual }\end{array}$ & \multicolumn{2}{|c|}{$\begin{array}{c}\text { Ramalan } \\
(\mathbf{F t}+1)\end{array}$} \\
\hline \multicolumn{2}{|c|}{ TAHUN 2021} & $\alpha=$ & $\alpha=$ \\
\hline Januari & 75,825 & 0 & 0 \\
\hline Februari & 51,530 & 75,825 & 75,825 \\
\hline Maret & 93,711 & 68,537 & 70,966 \\
\hline April & 134,718 & 76,089 & 75,515 \\
\hline Mei & 155,478 & 93,678 & 87,356 \\
\hline
\end{tabular}

Tabel 6. Perhitungan Rumus Konstanta 0.9

\begin{tabular}{lcl}
\hline \multicolumn{1}{c}{ Bulan } & $\begin{array}{c}\text { Permintaan } \\
\text { Aktual }\end{array}$ & $\begin{array}{l}\text { Ramalan } \\
(\mathbf{F t}+\mathbf{1})\end{array}$ \\
\hline \multicolumn{2}{c}{ TAHUN 2021 } & \multicolumn{1}{c}{$\boldsymbol{\alpha = 0 . 9}$} \\
\hline Januari & 75,825 & 0 \\
\hline Februari & 51,530 & 75,825 \\
\hline Maret & 93,711 & 73,396 \\
\hline April & 134,718 & 75,427 \\
\hline Mei & 155,478 & 81,356 \\
\hline
\end{tabular}

Setelah melakukan proses peramalan denan $\alpha$ (alpha) 0,1 sampai 0,9 selanjutnya dilakukan penentuan pola data nilai aktual untuk melihat jenis pola data apa yang digunakan pada peramalan tersebut [3].

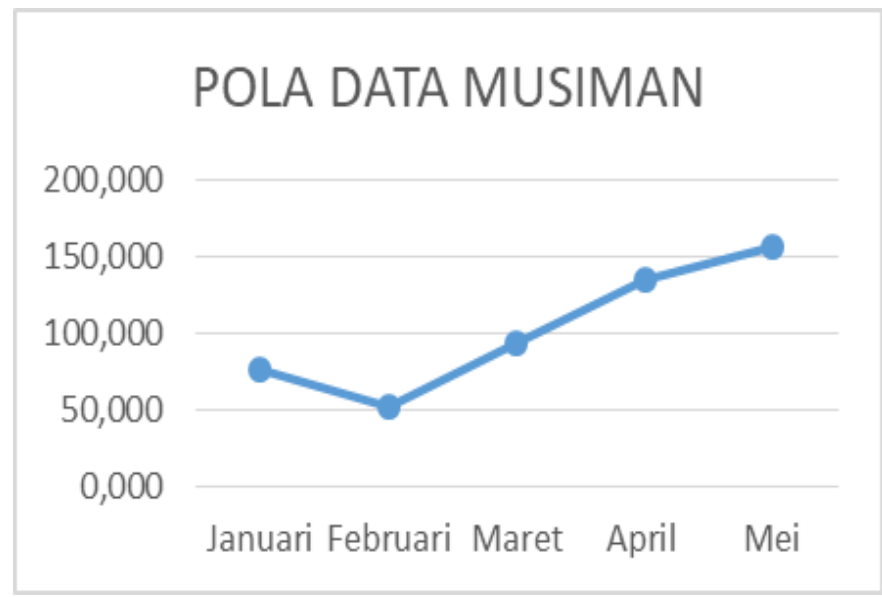

Gambar 4. Pola Data

Gambar 4 diatas adalah grafik pada data aktual penjualan tersebut menggambarkan pola data musiman yaitu karena terjadi suatu deret data yang dipengaruhi oleh faktor musiman atau banyaknya penjualan yang berbeda pada setiap hari maupun total penjualan bulanannya.

Pola data musiman juga termasuk pola data yang sesuai dan tepat dengan metode yang dipakai pada perhitungam data diatas yaitu metode Exponential Smoothing karena pola data yang mengalami fluktuatif yang sangat tajam perbedaannya dalam periode tertentu[9].

Setelah melakukan proses peramalan denan $\alpha$ (alpha) 0,1 sampai 0,9 dan pola data selanjutnya dilakukan perhitungan Mean Absolute Deviation (MAD) untuk menentukan hasil peramalan dengan nilai kesalahan/error terendah yang diambil sebagai hasil peramalan yang akurat[13][14]. 
Berikut adalah nilai error dari perhitungan MAD

Tabel 7. Perhitungan Nilai Error MAD

\begin{tabular}{cccc}
\hline Periode & $\begin{array}{c}\text { Alpha } \\
\text { (a) }\end{array}$ & $\begin{array}{c}\text { Nilai } \\
\text { Forcast }\end{array}$ & MAD \\
\hline JUNI & 0,1 & 152,952 & 26,857 \\
\cline { 2 - 4 } 2021 & 0,2 & 149,387 & 28,109 \\
\cline { 2 - 4 } & 0,3 & 144,617 & 29,373 \\
\cline { 2 - 4 } & 0,4 & 138,535 & 30,621 \\
\hline 0,5 & 131,092 & 31,825 \\
& 0,6 & 122,297 & 32,954 \\
& 0,7 & 112,218 & 33,980 \\
\hline & 0,8 & 100,980 & 34,873 \\
& 0,9 & 88,768 & 35,605 \\
\hline
\end{tabular}

Pada Tabel.7 diatas dapat dilihat bahwa MAD terkecil diperoleh dengan alpha 0,1 yaitu 26,857. Hal ini membuktikan forecast terbaik untuk meramalkan penjualan bulan berikutnya yaitu bulan Juni 2021 di Perusahaan Distributor Minuman Kemasan menggunakan alpha 0,1. Jadi nilai ramalan penjualan untuk bulan Juni 2021 pada periode ramalan bulanan disarankan menggunakan nilai alpha 0,1 karena dalam hitungan diatas menghasilkan error terkecil untuk nilai peralaman bulan Juni 152,952 carton.

\section{HASIL DAN PEMBAHASAN}

Menapilkan program analisis yang terkait dengan metode yang penulis gunakan sebagai berikut. 1. Tampilan Login Admin dan Kepala Cabang

GPM PT. GRAHA PRIMA MENTARI

$$
\text { Login }
$$

Masukkan Username dan Password

admin

Password

Login

Gambar 5. Tampilan Login 
2. Tampilan Master Produk

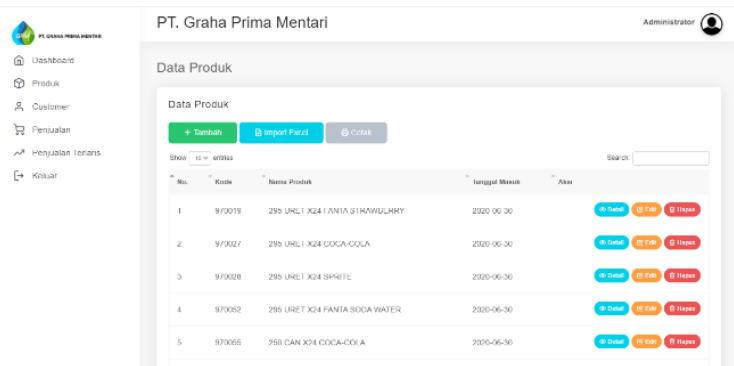

Gambar 6. Tampilan Master Produk

3. Tampilan Master Customer

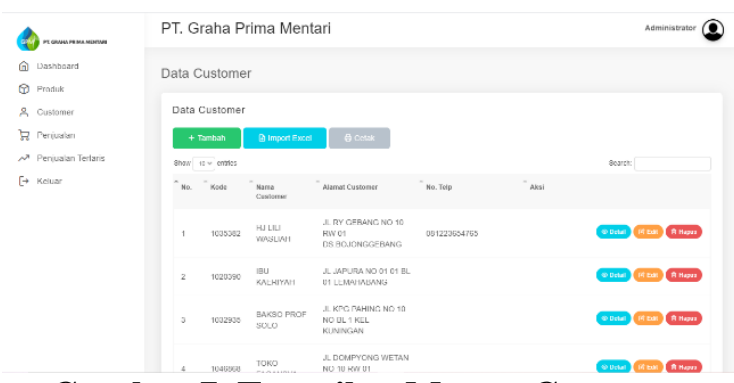

Gambar 7. Tampilan Master Customer

4. Tampilan Master Penjualan

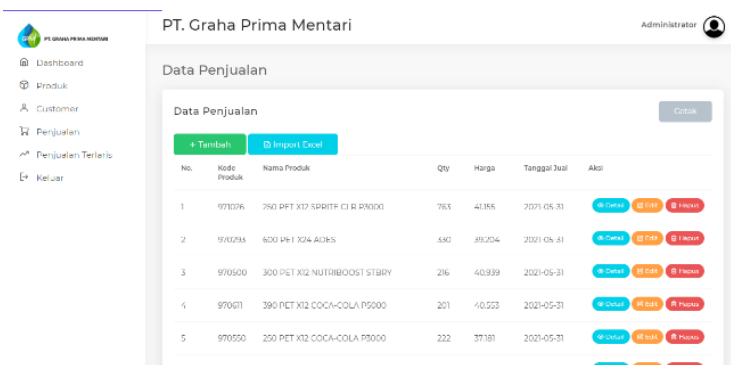

Gambar 8. Tampilan Master Penjualan

5. Tampilan Penjualan Terlaris

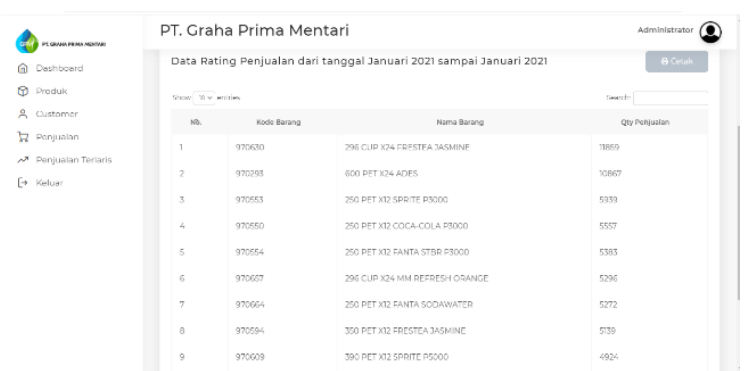

Gambar 9. Tampilan Penjualan Terlaris 
6. Tampilan Perhitungan Metode Exponential Smoothing

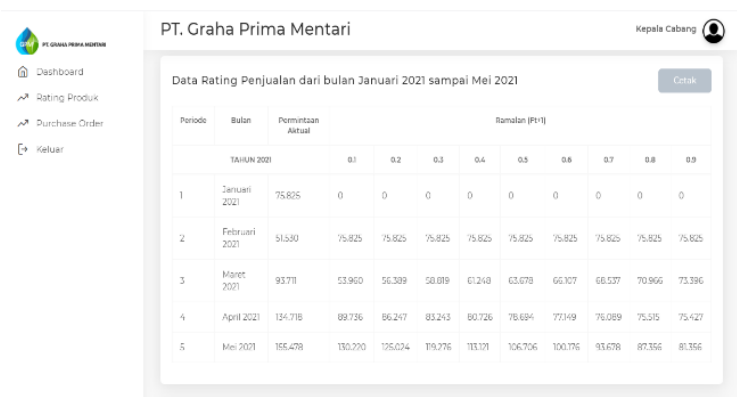

Gambar 10. Tampilan Perhitungan Metode

7. Tampilan Perhitungan Metode Reorder Point

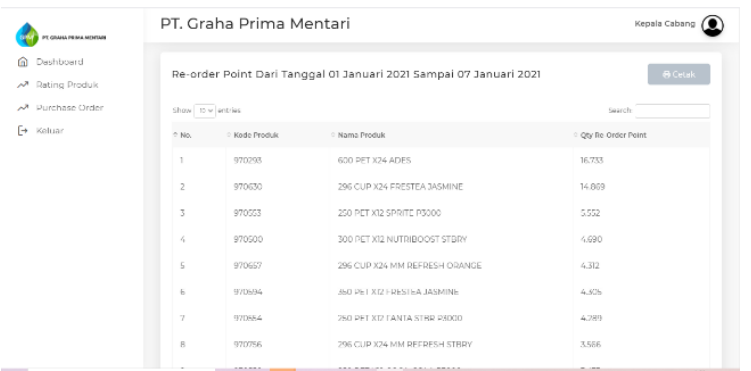

Gambar 11. Tampilan Reorder Point

8. Tampilan Laporan Purchase Order

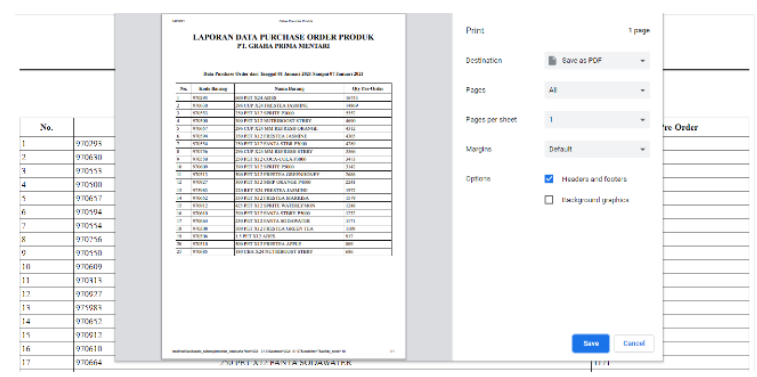

Gambar 12. Tampilan Laporan

\section{KESIMPULAN}

Berdasarkan hasil yang diperoleh dari pembahasan penerapan metode Exponential Smoothing pada sistem informasi penjualan terlaris di PT. Graha Prima Mentari, berikut kesimpulan dari penelitian yaitu sebagai berikut.

1. Dengan adanya web sistem informasi penjualan di PT. Graha Prima Mentari yaitu sistem informasi untuk menghitung penujualan harian menjadi rating penjualan terlaris dari produk yang paling banyak terjual sampai yang paling sedikit.

2. Dengan penerapan sistem penjualan terlaris yang baru, sistem data penjualan produk akan menjadi informatif sehingga mempercepat dan memudahkan admin dan kepala cabang untuk melakukan pendataan, perhitungan dan pencarian tanpa harus menghitung rating secara manual. 
3. Hasil penjualan terlaris dengan adanya sistem informasi ini dapat mengolah data purchase order juga untuk pemesanan terhadap produsen sesuai dengan kebutuhan aktual pasaran yang sudah di rating berdasarkan data penjualan harian sehingga lebih tepat.

4. Pada perhitungan rumus metode Exponential Smoothing pada sistem penulis mencoba semua nilai alpha dan dapat dilihat rata-rata hasil nilai peramalan dari alpha 0,1 sampai 0,9 adalah tengah-tengah yaitu perhitungan angka peramalan meningkat untuk nilai penjualan aktual yang normal dan perhitungan angka peramalan yang menurun untuk nilai penjualan aktual yang mengalami kenaikan.

5. Dapat disimpulkan bahwa nilai eror terkecil MAD (Mean Absolute Deviation) menggunakan alpha 0,1 yaitu 26,857 carton. Hal ini membuktikan forecast terbaik untuk meramalkan penjualan bulan berikutnya yaitu bulan Juni 2021 di Perusahaan Distributor Minuman Kemasan menggunakan alpha 0,1 begitupun sama dengan penjelasan teorinya yaitu semakin kecil nilai alpha yang digunakan, semakin smoot atau halus data deret waktu yang dihasilkan dan semakin kecil pergerakan data deret waktu.

6. Untuk data purchase order menggunakan rumus perhitungan reorder point dapat dilihat dalam angka data rating produk penjualan terlaris merupakan gabungan keseluruhan penjualan dari bulan januari 2021 sampai bulan mei 2021, dan dalam data penjualan keseluruhan periode tersebut tidak menjual semua jenis produk yang tersedia di distributor, melainkan hanya beberapa jenis produk saja yang laku dipasaran sehingga data purchase order yang akan dipesankan ke produsen hanya produk terkait saja.

\section{DAFTAR PUSTAKA}

[1] Alexander, M. Hatta, I. Susanto, "Implementasi Sistem Informasi Pembagian Insentife Dengan Menggunakan Metode KPI (KEY PERFORMANCE INDICATOR) Berbasis WEB", Universitas Catur Insan Cendekia, 2020.

[2] A. Mustofa, "Penerapan Metode FORECASTING untuk Meningkatkan Penjualan HANDPHONE Dengan Menggunakan DOUBLE EXPONENTIAL SMOOTHING", Universitas Nusantara PGRI, Kediri, Agustus 2018.

[3] A. Wahyu. A "Penerapan Metode Double Exponential Smoothing Untuk Estimasi Hasil Penjualan." TA A.Md.Kom., Universitas Pembangunan Nasional Veteran, Jawa Timur, 2012.

[4] Cristianto. "Perancangan Sistem Informasi Penjualan Berbasis Web Pada HI GADGET STORE." Skripsi S.Kom., Sekolah Tinggi Manajemen Informatika Dan Komputer (STIMIK), Batam, 2017.

[5] D. Gunawan, W. Joni .K. "Perancangan Sistem Informasi Purchase Order Menggunakan Metode Single Exponential Smooting," ISSN Jurnal Mahasiswa Aplikasi Teknologi Komputer dan Informasi, vol. 2, no. 1, pp. 13-18, 2020.

[6] D. Wulansari. "Sistem Pengendalian Persediaan Stok Barang Menggunakan Metode DOUBLE EXPONENTIAL SMOOTHING Dan ECONOMY ORDER QUANTITY (EOQ)." Skripsi S.Kom., Universitas Jember, Jember, 2016.

[7] E. Setyo .A., P. Prima .A., P. Lestari, "Pengembangan Sistem Informasi Peramalan Penjualan Guna Menentukan Kebutuhan Bahan Baku Pupuk Menggunakan Metode Triple EXPONENTIAL SMOOTHING", "ISSN Jurnnal Informatika Polinema, vol. 4, no. 1, pp. 35-42, November 2017

[8] F. Hasanah. "Penerapan Metode Exponential Smoothing Dalam Memprediksi Jumlah Peserta Didik Baru Di MAN 2 Kota Jambi." Skripsi S.Pd., Universitas Islam Negeri Sulthan Thaha Saifuddin Jambi, Jambi, 2019.

[9] F. Lamusa. "Peramalan Jumlah Penumpang Pada PT. ANGKASA PURA I (PERSERO) Kantor Cabang Bandar Udara Internasional Sultan Hasanuddin Makassar Dengan 
Menggunakan Metode HOLT-WINTERS EXPONENTIAL SMOOTHING." Skripsi S,Kom., Universitas Islam Negeri Alauddin, Makassar, 2017.

[10] G. Abi.S "Penerapan Algoritma Untuk Mencapai Pola Penjualan Di Cafe." Skripsi S.Kom., Universitas Sanata Dharma, Yogyakarta, 2017.

[11] Kurniagara, "Penerapan Metode EXPONENTIAL SMOOTHING Dalam Memprediksi Jumlah Siswa Baru,’ISSN Jurnal Pelita Informatika, vol. 6, no. 1, pp. 19-25, July 2017.

[12] K. Sulistya.W. "Pengembangan Sistem Informasi Kartu Menuju Sehat Sebagai Alternatif Pengelolaan Posyandu Secara Digital."Skripsi S.T., Universitas Negeri Yogyakarta, Yogyakarta, 2014.

[13] N. Putu. Y. S. "Penerapan Metode Exponential Smoothing Pada Peramalan Penjualan Penentuan Kuantitas Produksi Roti." Skripsi S.Kom., Universitas Halu Oleo, Kendari, 2016.

[14] O. Nurdiawan, N. Salim, "Penarapan Data Mining Pada Penjualan Barang Menggunakan Metode Metode NAÏVE BAYES CLASSIFIER Untuk Optimasi Strategi Pemasaran,"ISSN Teknologi Informasi dan Komunikasi, STMIK Subng, April 2018.

[15] R. Dzickrillah .L., E. Santoso, B. Rahyudi, "Prediksi Penjualan Roti Menggunakan Metode EXPONENTIAL SMOOTHING", ISSN Jurnal Pengembangan Teknologi Informasi dan Ilmu Komputer, vol. 3, no. 5, pp. 4933-4941, Mei 2019.

[16] S. Rahmatullah, Mukrim, Monica, N. Pramitha, "Data Mining Untuk Menentukan Produk Terlaris menggunakan Metode NAÏVE BAYES,'ISSN Jurnal Informasi Dan Komputer, vol. 7, no. 2, pp. 57-62, July 2019.

[17] S. Said. "Peramalan (FORECASTING) Volume Penjualan Dengan METODE EXPONENTIAL SMOOTHING." Skripsi S,Kom., Universitas Islam Negeri Alauddin, Makassar, 2011. 